\title{
Repositioning Physical Education in Schools
}

\author{
Sukirno \\ Sriwijaya University \\ Indralaya, Indonesia \\ sukirno_unsri@yahoo.co.id
}

\begin{abstract}
This paper aims to provide ideas in an effort to restore the role of physical education as a whole. Because until now the implementation of physical education they have yet according to the principles of physical education. Physical education as a subject in schools aims to improve physical fitness, as well as forming the character of a good learner, relating to morality, ethics, and honesty. The implementation of the physical education is no different from other subjects, only the implementation in the field of physical education is more emphasis on physical activity, tailored to the needs and character of students. There are still many physical education teachers in the implementation of teaching and learning activities still, tend to other forms of exercise. So it is not in accordance with the rules of teaching physical education, more emphasis on physical performance. So the main purpose of physical education to improve the physical fitness of students is not reached, even very low, nationwide only about $7 \%$. Based on the explanation, it is necessary to reposition physical education, with regard to the implementation of teaching and learning activities, learning materials, facilities, and infrastructure, including monitoring and evaluation system.
\end{abstract}

Keywords-Repositioning; Physical Education; Sports and Physical Fitness

\section{I.INTRODUCTION}

Education is a basic effort to prepare students for guidance, instruction and training for its role in the future [1]. Physical education is an integral part of the education of actualizing physical activity. Physical education has long been introduced since the Dutch colonial era through his school, MULO, HBS, and HIK are often known as a subject in school calisthenics. In the '50s Lessons exercise carried out and designated as subjects in school physical education from Sekolah Rakyat (SR), which is now known Elementary School (SD) to university. Due to physical education has a high value, where the philosophy of physical education and sport will give directions for professional development [2]. So through physical education and sports activities are expected to establish the professionalism of someone who practiced in all fields.

After a change in the curriculum of the Ministry of Education and Culture, the physical education changed its name to Sports Health (orchestra). nearly 32 years of Sports Health abbreviated curriculum orchestra, the impact of sports in Indonesia become very alarming existence, in all sporting activities, especially sports students, especially the students is very low fitness. Based on the results of a 2006 study fitness data shows that $37.40 \%$ categorized as very less, $43,90 \mathrm{n} \%$ less, being $13.55 \%$, only $5.15 \%$ have good fitness [3].
Based on these results the fitness of students in Indonesia is only $5.15 \%$ are categorized either. It's very alarming, associated with a very low fitness will automatically affect all sports activities nationwide. So sports Indonesia decreased performance due to low physical fitness Indonesian society in general. This is all due to the low capacity of physical education teachers as spearhead the development of physical fitness in society has an education. This is due to the implementation of teaching and learning activities undertaken by teachers not the goal-oriented curriculum, namely to increase the physical fitness of students. Because of the teaching and learning activities incompatible with the principles of physical education, where the implementation of learning should emphasize on physical performance multilaterally. To optimize the performance of the physical one is a pulse meter. The pulse rate lower limit and the upper limit must be reached between 140-180 beats per minute [4].

This means that learners in physical activity should reach a pulse of 180 times per minute. To achieve the expected pulse, then physical activity should be optimal learners, through the material physical education conducted by physical education teachers. Because the teacher is a factor that is very influential on the low quality of education. Guru is one important component that determines the quality of graduates [5]. Based on the reference, it is clear the low level of physical fitness of students in Indonesia, caused by a physical education teacher quality is very low. As a result of the implementation of teaching and learning activities are still oriented to the sport, through the patterns of practice, making it less motivating learners. The impact many children are reluctant to undertake such activities.

Physical education is the foundation for sustainable development of the sport [6]. This means that when physical education is good, then the tasks automatically will make it easier to find potential sportsmen to be developed further in order to print the athletes reliable. As the era of the '60s through the optimal physical education, Indonesia became a respected country in the region for the sport. Because of the role of physical education done throughout life in order to motivate people to stay active and healthy [6].

That is done through physical education, the whole community enjoys to make healthy culture through active physical activity. Because physical activity is a need to promote a culture of healthy living every individual. So that, in turn, will increase in physical freshness. The climax of the Games Asian countries in 1962, Indonesia placed second after Japan Asian continent. This indicates the success of the Indonesian people 
put physical education as a pillar of national development through physical education and sport. Due to physical education and sport are also able to build the nation's character.

In general, physical education aims to improve the physical fitness of students, to have a good physical fitness, it will provide a balance between theory during their lessons in the classroom practice in the field through physical education. So there will be a balance between motion and rest. In accordance with the purpose of physical education is to form students into a healthy human body and spirit, to be fully human.

Physical education has been reinstated as the era of the '60s, but the facts on the ground a lot of physical education teachers in implementing the learning activities are still oriented sport. Such as providing drill practice sprints, such as the activities of training, there is even a physical education teacher at the elementary school provides training to run $10 \mathrm{~km}$, including in sports games, such as volleyball games with volleyball original, teach football with soccer ball genuine. So the concept is similar to the concept of sports training achievement-oriented. Supposedly the implementation of physical education teaching and learning activities should be tailored to the child's character. Children ages Elementary School (SD) including the age of growth, that growth to run normally, the activities must be in accordance with the child's development. So the physical activity should be oriented towards fitness [7].

While the word sport is indigenous Indonesian word and not from a translation of Sport, the sport means to cultivate, cook attempts to change something more complete. Physical form men [8]. While the variety of sports include (1) physical education, (2) health, (3) recreation, (3) sport, and (4) dance. In the current era of the sport said more achievement-oriented, to create a champion, it is more likely in training, meaning extreme human form. So physical education is part of the sport, where the activities of emphasis on physical activity instead of emphasizing on knowledge or rote.

Physical education is an education component, clearly have a purpose in improving the cognitive, affective and psychomotor, but cognitive physical education should not be delivered on specific activities in the room as well as other subjects, but can be performed in conjunction with the activity or physical activity that is ongoing in the field, with regard to what is being done. So the emphasis on education movement (physical activity), aims to improve the health and freshness of learners.

It is time for the physical education teachers should have changed the new paradigm of the concept of the sports switch on the concept of physical education intact, oriented to increase the quantity and quality of motion as a whole, which is adapted to the character of students, not training exercise aims to improve achievement. Physical Education Teaching and Learning Activities at each implementation (KBM), must please refer to the learning PAIKEM, Creative Innovative Active Learning Effective, and fun). Thus learners will be optimized to perform or feel the motion to meet the needs of the body to move in carrying out their daily activities.

\section{A. Physical Education}

Physical education is a process of interaction between learners with the environment, through physical activity are managed systematically towards men [5]. Physical education is a process of socialization via physical activities and sports that are selective for achieving the education in general [9]. Where the purpose of physical education is not just to get a healthy life but higher, to improve fitness (physical fitness).

This means that people who have physical fitness are a person who is able to do some physical activity did not experience significant fatigue [10]. This means that people who have a good level of physical fitness, after a full day of activities was not until experiencing high levels of fatigue (very tired), are able to do other work. In addition, physical education is also an activity that can promote the development of social and moral aspects of the child [11]. Morale is associated with an attitude component, cognitive and behavioral.

Physical education is an effort to improve the human aspect of the whole human widened, the physical and spiritual health, which includes organic neuromuscular, intellectual, emotional. It says that physical education has a health value. Healthy according to WHO is healthy spiritual body free from defects and weaknesses. Physical education is an educational process, which is an integral part of the educational process as a whole. Through physical activity as a means or an attempt to achieve clear objectives. The purpose of physical education as well as other educational objectives that include physical realm motor, affective and cognitive [12].

Based on the explanation above in accordance with the definition of physical education. Namely, education to actualize the potential of human activity that involves an attitude follow the work to be given the form, content, and direction towards the determination of personality in accordance with the ideals of humanity [13]. If we talk about personality clearly covers all aspects, including, attitude, mental, cognitive, moral ethics which deals with the whole man, so obviously, physical education is a tool for shaping a person's character. Based on some opinions related to physical education. So the question of physical education in the study is an educational activity that is listed in the curriculum from primary school to university, where activity is more emphasis on physical performance aims to improve physical fitness learners (students) or student

Although physical education there is cognitive, does not mean the learning of physical education should be given the material on the theory of sharing matters relating to physical education and sport. But the activity or physical activity done on learners must have described what has been learned, in addition to doing physical activity will also be able to optimize cognitive function, particularly the function of the brain on the right who think divergent that creates ideas and creativity to get new things, including efforts to improve emotional intelligence. In general, in doing physical activity required to act fast, precise and accurate [14]. This means that students are directed participants to think quickly, to conduct a rapid, precise and accurate

Sports activities are also common practice, which prioritizes physical activity, containing elements, play, and fight (against yourself, nature and others) are performed in the fair play. If the sports activities conducted fair play, then these activities can be used as a good educational tool. Based on this concept may be the emergence of the term sports education in Indonesia around 1960s. Following the Law No. 2 the year 1989 on National Education System, then reverted back to physical education physical education, that is, before the 1960s. For that, we are grateful that the repositioning of physical education in accordance with the expected goals of forming students into 
shape and character. Although the implementation is not yet fully in physical education. Because in general physical education teachers that there are still obsessed with health sports (orchestra). More sporting orientation on performance, while the physical education emphasizes education goals related to health and fitness as well as the values of personality [15].

\section{B. Implementation of Physical Education}

Although health sport abbreviated curriculum (orchestra) is no longer applied again and now has embraced physical education curriculum. But implementation on the ground remains very difficult to change the maid set sports teachers to the concept of physical education. Because until now there are many physical education teachers in implementing the teaching and learning activities in the field are still inclined at sporting events, where the implementation is still impressed in workouts. Examples there are many teachers in elementary school (SD) to train learners to practice running $10 \mathrm{~km}$, and they are proud that their students are able to do run $10 \mathrm{~km}$. In fact, many developing among the public, that the teacher is considered successful if these schools are often won various events (games) that have been followed. Based on these assumptions, the many schools in implementing the teaching and learning activities (KBM) is identical with sports training.

So it is not infrequently the gym teacher in elementary school (SD), in athletics teaches children were told to run for kilometers, with the hope that he will win the $10 \mathrm{~km}$ run, or run long distances. Supposedly in the implementation of learning refers to the physical education, all materials must be associated with other forms of the game, so that students would love to do. Since the development of children aged 10 and under are still oriented at the time of play. Suppose material sprints can be done through the implementation of green game black, Bentengan, born-Bonan, and others.

In addition to the physical education curriculum in schools is still oriented to sports skills, such as gymnastics, athletics, football, as well as sports teachers in making SATPEL in the implementation of the learning process still refers to material sport, the reason they were when the school did not win will blamed by the principal, superintendent or school owner. Because they do not understand what it is physical education, including on the goal.

Such a condition has lasted long enough, during the implementation of the curriculum Sports Health (orchestra), then to restore the physical education at the actual position takes time, and the most basic need to make changes in the total system of education in Indonesia, especially in physical education. For so it should be in a physical education teaching and learning activities must be adapted to the character of students, which is adapted to the purpose of physical education itself, which is to increase the freshness of the learner and not scoring champion.

Physical education correct in its implementation must be tailored to the needs of learners, in an effort to improve the physical, motor, cognitive and affective children, so the development of children will grow optimally. Implementation of physical education should involve a range of motion (multilateral) and a lot of emphasis on physical movement [16]. This means that the implementation of physical education should be oriented to the forms of the game. Thus physical education will have a large role in helping learners to be fresh and of quality in order to meet its future, both as an athlete and in other professions. Because basically athletes who have gained high achievements in academics (students). Where the main requirement of an athlete is physical fitness excellence.

In order to reposition the physical education and sports coaching system in the country, needs to be clearly regulated. So there is no ambiguity in the implementation and understanding of physical education with sports. It is important that teachers carry out sports activities in the learning process is no longer delivered material is identical to the physical education exercise, and vice versa.

\section{Material Physical Education.}

To achieve the purpose of physical education in the future, the necessary materials related to physical activity (motor). All physical education material should be adjusted to the level of growth and development of children. For children Kindergarten and Primary School then, the emphasis of physical education material aimed at developing awareness of motion [17]. Associated with the development of basic movement skills, which include locomotor movements (movements that move), non-locomotor (movement in place) and manipulative (a blend of several motions). For the next stage is the development of basic movement skills, and then proceed to the smoothing of motion. While in High School and College entered into highlevel motor skill. To this level is already allowed to use materials sport (sport), or other forms of games that have been modified from the existing motor skills in sports. Based on the explanation above, the material in physical education is not oriented skills that must be learned but oriented to the needs of learner's movement to improve physical health, organic, mental, emotional, social and intellectual.

Sports material particularly evident in sports achievement that is raw for example basketball, the whole world will be using the same rules, both in terms of size, large ball, and the game rules. Thus, to achieve the purpose of sport, the material used depends on the type of sports studies. In physical education course is not the same as exercise. Examples of physical education material comparisons with the sport.

In physical education material is a jumping motion locomotor movements can be done with a prefix, without prefix, jump to the left, to the right, jump over an obstacle or without obstacles. But in sport (sport) jump event known only two, namely the high jump and long jump. So that the material that is taught should be based on the needs of the second jump.

Material throws in physical education material known as a throwing motion with the manipulative skills such as throwing a big ball, small ball, throw with wood, iron and so on. While the material in sport is discus and javelin and shot put.

Based on the examples mentioned above, it can be concluded in the sport of throwing material may be used in physical education material origin of the level of difficulty of motion, and the tools used must be adapted to the needs and level of development of learners. The material cannot be used for physical education in sports, physical education because the material is a modification of the sport adapted to the character and needs of learners.

\section{Teachers and Students}

Implementation of physical education should be no teacher and no students (children) while on the implementation of sports 
activities should be no coach and no athletes. In the process of education and training even though there are some similarities, but there are many differences. The equation is learning motor skills and their interaction. The difference is that the teachers put more emphasis on the development of learners in all aspects in a balanced (physically and spiritually). Coaches develop in all aspects of your athletes in accordance with the needs of branches of sport, emphasis on sports skills learned. So frequent disharmony in the growth of his body, such as badminton players have been great arm side, hurdler legs often long side, a discus thrower woman's body like a man, and there are many other examples.

So the physical education teacher education-oriented professional with students who come from various layers and groups. Meanwhile, the achievement-oriented sport that is intended for children who have a talent and interest, adjusted for the sports branch. Children who are not talented in the sport would not be likely to be high-achieving athletes, although coached by competent [13]. That is if the sport were first trained to look for children who have a talent in sports to be trained. But if the physical education of all children should be given comprehensive and multilateral movements).

\section{E. Monitoring System}

In an effort to reposition the physical education then all the components involved must have the same perception in the mission and vision, including the physical education supervisors are involved directly in the process of physical education. Based on observations in the field with some changes in the system of physical education, then the supervisor of physical education untouched by physical education, necessary updates, and guidance on the concepts of the new physical education. As an example, there is a physical education teacher who has been trained in physical education, and teachers to teach the material using a throwing stick with a specific goal, came supervisor, and he scolded the teacher who was teaching physical education by asking about various things including whether there in the curriculum throwing target. That is because of only a trained physical education teacher's physical education. For that inspector should first be trained with regard to physical education and physical education teachers, in order to avoid misunderstanding about physical education. In addition, in the implementation of the upgrading of physical education should involve all the relevant components in order to have a vision, a mission and a shared perception of the implementation of physical education in schools. So that no longer minded that school success related to physical education is measured by winning the sport he participated in several competitions.

\section{II.INFRASTRUCTURES}

Facilities and infrastructure are used in physical education teaching and learning activities should be done modifications. This is in accordance with the opinion of [16]. That equipment or tools in teaching physical education can be modified to fit your needs. Based on these explanations, the infrastructure used in the conduct of physical education does not need to match the size of that found in the sport, but the most important is that it can be used to develop various aspects of movement in accordance with the purpose of physical education and are not harmful to students. This means that all the facilities and infrastructure contained in the sport can be done by modifying, including rules that will be applied. Implementation of physical education should be oriented towards the environment. Unlike the sport should be in accordance with the existing rules on the parent branch of sport.

Examples of infrastructure to teach the game of volleyball is not necessary to use an existing field size in volleyball, including equipment to be used. But simply use the field provided, whereas the tool, the ball of what was important resembles volleyball. But the implementation of learning activities leading to the game of volleyball. The main goal of how children move to learners' needs can be met. Such as physical, organic, neuromuscular, cognitive, and attitude, including positive values contained in the game, including the nature of sportsmanship, honesty, and cooperation.

To support the implementation of physical education in schools should be supported by the facility or field, whether the field is open, or closed. It is recommended to the national education in preparing school buildings must also consider the preparation playground facilities for children.

\section{III.CONCLUSION}

Based on the discussion, it can be concluded as follows; (1) In general I've done repositioning of physical education, meaning that enforcement of health Sports curriculum (orchestra) is not treated anymore because they do not have a positive impact on the level of physical fitness of students. (2) despite tight repositioning, but its implementation in the field is still a lot of physical education teachers in other teaching physical education, they tend to be on exercise, (3) there is still no common perception in all parties associated with physical education, so that many think, that the success of the school in physical education is measured when winning various events competitions, (4) in general schools/government has not been able to prepare an adequate infrastructure for physical education activities.

\section{IV.REFERENCES}

[1]. Sukarna: 1998, Keterpaduan Pendidikan Jasmani dan Olahraga dalam sistim Pendidikan di Indonesia Makalah Seminar Nasional, Medan: Panitia Seminar Olahraga Nasional

[2]. Toho Cholik Mutohir.2002. Olahraga sebagai Wahana Meningkatkan Ketahanan Nasional, Forum Olahraga, Jakarta. Dijen Olahraga Depdiknas.

[3]. Toho Cholik Mutohir dan Ali Maksum. 2007. Sport Development Indekx. Jakarta Kemnegpora.

[4]. Junusul Hairy. 2000. Daya Tahan Aerobik. Jakarta: Direktorat Jendral Olahraga Depertemen Pendidikan Nasional

[5]. Harsuki. 2003, Perkembangan Olahraga Terkini Kajan Para Pakar. Jakarta: PT., Raja Grafindo Persada

[6]. Rusli Lutan. 2001. Pembaru Pendidikan Jasma ni di Indonesia, Jakarta: Depdiknas.

[7]. Endang Widyastuti dan Agus Suci. 2010. Pendidikan Jasmani Olahraga dan Kesehatan. Jakarta.: Pusat Perbukuan Kementrian Pendidikan Nasional

[8]. Ateng. Abdulkadir 2003, Pengembangan Sistim Pendidikan Jasmani. Fakultas Ilmu Keolahragaan Universitas Negeri Jakarta.

[9]. _ _ KDI Keolahragaan. 2000. Ilmu Keolahragaan dan Rencana Pengembangannya. Jakarta: ISORI

[10]. Sumosardjuno Sadoso: 1996, Pengetahuan Praktis Kesehatan dalam Olahraga, Jakarta: PT.Gramedia Pustaka Utama 
[11]. Ibrahim Rusli: 2001, Pembinaan Prilaku Sosial Melalui Pendidikan Jasmani, Jakarta: Depdiknas

[12]. Annarino, AA, Cowell, CC., and HW, 1980, Curriculum Theory and Designs in Physical education. London: The CV Mosby Company.

[13]. Sudibyo Styobroto. 2000. Psikologi Olahraga. Jakarta: CV., Jaya Sakti

[14]. Rusli Ibrahim. 2001, Pembinaan Prilaku Sosial Melalui Pendidikan Jasmani. Jakarta: Depdiknas.

[15]. Toho Cholik Mutohir.2002. Gagasan-gagasan Tentang Pendidikan Jasmani dan Olahraga. Jakarta: ISORI

[16]. Krotee.,L March and Bucher A., Charles. 2007. Management Physical Education and Sport. Las Vegas: CarlislePublishing Services

[17]. Corbin, CB., 1980., Texbook of Motor Development. Dubuque : Wm, C. Brown Publisher 